\title{
Press and Dryer Roll Surfaces and Web Transfer Systems for Ultra High Paper Machine Speeds
}

Quarterly Status Report For the period January 2000 through March 2000

On

Project DE-FC36-99GO10384

\section{T. F. Patterson}

May 1,2000

The purpose of this quarterly report is to provide an overview of the project including key tasks, schedules for completion of tasks and to document accomplishments.

\section{Project Overview}

Project Staff: Timothy Patterson is principle investigator of the project. Jere Crouse, recently retired from Beloit Corporation, and Fred Bloom, Professor, Northern Illinois University, are consultants. The IPST Staff working on key aspects of the project are:

Fred Ahrens, Professor

Yulin Deng, Associate Professor

Hiroki Nanko, Associate Professor

Shana Mueller, Assistant Engineer

Project Objective: The objective of the project is to provide fundamental knowledge and diagnostic tools needed to design new technologies that will allow ultra high speed web transfer from press rolls and dryer cylinders.

Fundamental Questions: From a fundamental standpoint, we expect that roll surface performance depends on the composition of contaminants that deposit on those surfaces during use, as well as the materials and finishing techniques used in manufacturing these surfaces. We need to understand; the contamination process, the influence of contamination on work of adhesion, the roles of surface topology, film splitting, and process conditions on web transfer.

1. What is the status of the technical scope of work? Answers should be tailored to the tasks in the Statement of Work that are being performed.

Task 1.

Sampling for the purposes of obtaining enough data to formulate "contamination recipes" for the Contamination Test Stand is complete. We are currently making arrangements with a supplier company to continue this activity. The sample collection will be done as an "in-kind" contribution to the project. The objective is to provide a more extensive data base on contamination.

\section{Task 2.}

Task 2 is complete.

\section{Task 3.}

The "dryer can" configuration of the device is complete and is being used for testing. The add-on device that will be used for simulating pressing applications has been fabricated and is being assembled. This will be complete by the middle of May.

\section{Task 4.}

Web adhesion and picking experiments using uncontaminated coupons are in progress. This data will be used as a control for later tests using coupons that will be contaminated using the CTS. Completion of the task will occur late summer 1999.

Coupon contamination under controlled conditions using the CTS has begun. This is will be an ongoing task, as there are a number of variables to be evaluated. Completion of the task will occur mid summer 1999. 


\section{Task 5.}

Work is in progress. There are two areas of focus that will be integrated as the work progresses. The first area is web adhesion and cohesion properties and relating those properties to the results from the WADS experiments. The current effort is directed at developing a model that relates sheet properties, that can be measured using standard techniques, to the sheet internal cohesion. The cohesion can then be compared directly to the adhesion measured using the WADS. The second area is web dynamics. In this area the effort is on modeling the impact of web adhesion on the web dynamics as it leaves the roll and immediately afterward. This work will be compared with high speed video of actual web transfer.

\section{Task 6.}

No progress to date. This task will be completed during the $3^{\text {rd }}$ year of the project.

2. What is the completion status for each task and/or subtask? Provide an estimate of completion dates for each task and/or subtask.

Task 1

Complete.

Task 2

Complete.

Task 3

The basic device is complete.

Task 4

In progress.

Task 5

In Progress.

Task 6

No progress to date. This task will be completed during the $3^{\text {rd }}$ year of the project.

3. Are there any significant program/project tests or demonstrations in the next four months? This pertains to work outlined in the Statement of Work.

Testing on the CTS and the WADS will begin (Task 4)

4. Are there upcoming conferences at which project related papers will be presented? This pertains to work outlined in the Statement of Work.

Papers on the theoretical work associated with Task 5 are being prepared. No conference/journal has yet been selected.

5. If there are any variances to cost or schedule, what are the reasons for these? If the project schedule has changed submit an updated schedule with dates referring to each task.

None planned at this time. 


\section{DISCLAIMER}

This report was prepared as an account of work sponsored by an agency of the United States Government. Neither the United States Government nor any agency thereof, nor any of their employees, make any warranty, express or implied, or assumes any legal liability or responsibility for the accuracy, completeness, or usefulness of any information, apparatus, product, or process disclosed, or represents that its use would not infringe privately owned rights. Reference herein to any specific commercial product, process, or service by trade name, trademark, manufacturer, or otherwise does not necessarily constitute or imply its endorsement, recommendation, or favoring by the United States Government or any agency thereof. The views and opinions of authors expressed herein do not necessarily state or reflect those of the United States Government or any agency thereof. 


\section{DISCLAIMER}

Portions of this document may be illegible in electronic image products. Images are produced from the best available original document. 